\title{
The Characteristics of Heavy Metals of the Groundwater in the Gangue-Filled Reclamation Area
}

\author{
P.P. Zhang \\ 1.College of Geoscience and Surveying Engineering, \\ China University of Mining and Technology (Beijing), \\ Beijing 100083, China; \\ 2. School of Civil Engineering, Henan Institute of \\ Engineering, Zhengzhou, 451191, China
}

\author{
M.X. Liang \\ College of Geoscience and Surveying Engineering, China \\ University of Mining and Technology (Beijing), Beijing \\ 100083, China;
}

\begin{abstract}
In order to study the characteristics of heavy metals of the groundwater in the gangue-filled reclamation area, the heavy metals were investigated at Ju-Ji Coal mine with high groundwater level. The samples of the groundwater were gathered in the gangue-filled reclamation area at different time, studying the .characteristics of heavy metals of the groundwater. The results were as follows: the heavy metal content of the $\mathrm{Cd}, \mathrm{Hg}$, $\mathrm{As}$ and $\mathrm{Pb}$ increased with the increase of reclamation time. The heavy metal content of groundwater associated with the reclamation time in linear time.
\end{abstract}

Keywords-Groundwater; Heavy Metals; Reclamation Time; Gangue-Filled Reclamtion

\section{INTRODUCTION}

The coal gangue is the directly discharged solid waste of coal mining and processing, which accounts for $10 \%$ $-20 \%$ of the emissions of coal production [1]. As the filling coal gangue material of coal mining subsidence, not only to restore the use of the mechanisms subsidence, but also to solves the problems of coal gangue occupied land and damage the ecology. The coal gangue contains a variety of heavy metals, and heavy metals $\mathrm{Cd}, \mathrm{As}, \mathrm{Hg}$ and $\mathrm{Pb}$ toxicity, it is difficult degradation by biological effects. The coal gangue under the long-term influence of groundwater, natural rainfall and other conditions, which could easily lead to the release of heavy metals and affect the heavy metal content of groundwater, and then enter the body to threaten to the human health by the way of the food chain. Groundwater of reclamation is an important part of the ecological environment rehabilitation. The study on the features of the time evolution of the coal gangue affecting the heavy metal's content in the reclamation of groundwater, which has important significance for the safe use of the groundwater in the reclaimed area.

Currently, the study on the pollution of the heavy metals in the waters of coal mining subsidence drew relatively significant concern of many experts and scholars. There are many researches on the heavy pollution of the waters in coal mining subsidence [2-6]. While there are a little researches on the pollution and the time evolution characteristics of the groundwater of the coal gangue of filling reclaimed area in the coal mining area.

This article chooses the reclaimed area in the Juji's coal mining area as the object of study, which is in high phreatic level of the plains region. On the basis of filed investigation and laboratory analysis, we study on the features of the time evolution of the coal gangue affecting the heavy metal's content in the reclamation of groundwater.

\section{MATERIALS AND METHODS}

\section{A. Overview of the Study Area}

The coal mining of Juji is in the city of Yongcheng, which is located in the high groundwater level of plain area. The coal mining of Juji takes reclamation technique in the process of reclamation, which is striping topsoil and filling coal gangue and then covering soil with $60 \mathrm{~cm}$ on the coal gangue in subsidence area. At the same time, we lay two monitoring wells in reclamation area to monitor the contamination of the groundwater's heavy metals. Before reclamation, the area is the basic farmland which has no heavy metal contamination. The elevation of underground water level in the reclamation area is below the waste rock filling layer.

\section{B. Sample Collection and Processing}

The sample point is the two monitoring wells in the reclamation area. And selecting the nearby household well as a control sample, without the mining subsidence affected. When sampling monitoring wells, each sampling copy comes from the two wells and marking the A and B according to the sequence of tests. The sampling time is from December 20, 2012 to December 20, 2014.And taking once every six months for a total of five samples. In the first sampling, sample the household well water as the control sample. The samples will be sent to the lab for analysis. We took the samples of coal gangue from the reclamation land which is nearby the two monitoring wells and the sample of soil from the nearby individual well on June 20, 2012. And then send the samples for analysis in the lab. 


\section{Testing Methods and Data Processing}

The method of testing $\mathrm{Cd}, \mathrm{Pb}$ is atomic absorption spectrophotometry. The method of testing $\mathrm{As}$ and $\mathrm{Hg}$ is inductively coupled plasma method.

The statistical analysis of the data is using by the SPSS19.0 and the Microsoft Excel 2013 statistical software.

\section{RESULTS AND ANALYSIS}

\section{A. Heavy Metal Content of Groundwater Reclamation Area}

After determination, the heavy metal content of groundwater of reclamation area and control groundwater of individual well is shown by tab.1 and tab.2. The heavy metal content in the soil nearby individual well and in the coal gangue of reclamation land is shown in the tab.3.

Tab.1 Heavy Metal Content of Different Time in Groundwater of Reclamation Area $\left(\mu g \cdot L^{-1}\right)$

\begin{tabular}{|c|c|c|c|c|c|c|c|c|}
\hline Reclam & $\mathrm{Cd}$ & & $\mathrm{Hg}$ & & As & & $\mathrm{Pb}$ & \\
\hline $\begin{array}{l}\text { Time(a } \\
\text { ) }\end{array}$ & A & B & A & B & A & B & A & B \\
\hline \multirow{2}{*}{0.5} & \multirow{2}{*}{0.519} & 0.5 & 0.2 & 0.3 & 6.3 & 6.5 & 8.9 & 8.8 \\
\hline & & 36 & 96 & 13 & 3 & 2 & 9 & 3 \\
\hline \multirow{2}{*}{1.0} & \multirow{2}{*}{0.521} & 0.5 & 0.2 & 0.3 & 6.3 & 6.5 & 9.1 & 8.8 \\
\hline & & 48 & 97 & 17 & 7 & 6 & 2 & 9 \\
\hline \multirow{2}{*}{1.5} & \multirow{2}{*}{0.517} & 0.5 & 0.2 & 0.3 & 6.4 & 6.6 & 9.2 & 9.1 \\
\hline & & 25 & 99 & 21 & 6 & 8 & 3 & 1 \\
\hline \multirow{2}{*}{2.0} & \multirow{2}{*}{0.526} & 0.5 & 0.2 & 0.3 & 6.5 & 6.7 & 9.2 & 9.2 \\
\hline & & 46 & 96 & 24 & 2 & 5 & 1 & 3 \\
\hline \multirow{2}{*}{2.5} & \multirow{2}{*}{0.531} & 0.5 & 0.3 & 0.3 & 6.5 & 6.8 & 9.3 & 9.2 \\
\hline & & 50 & 03 & 27 & 8 & 2 & 3 & 9 \\
\hline \multicolumn{9}{|l|}{ B. } \\
\hline \multicolumn{9}{|c|}{$\begin{array}{l}\text { Tab.2 Heavy Metal Content in Control Groundwater of Individual } \\
\text { Well }\end{array}$} \\
\hline \multicolumn{2}{|c|}{ Chemical Element } & & $\mathrm{Cd}$ & \multicolumn{2}{|c|}{$\mathrm{Hg}$} & As & \multicolumn{2}{|l|}{$\mathrm{Pb}$} \\
\hline \multicolumn{2}{|l|}{ Content } & & 0.131 & \multicolumn{2}{|c|}{0.089} & 5.82 & \multicolumn{2}{|c|}{6.15} \\
\hline
\end{tabular}

Tab.3 Heavy Metal Content in the Soil Nearby Individual Well and in the Coal Gangue of Reclamation Land ( $\mathrm{mg} / \mathrm{kg}$ )

\begin{tabular}{ccccc}
\hline Sample & $\mathrm{Cd}$ & $\mathrm{Hg}$ & $\mathrm{As}$ & $\mathrm{Pb}$ \\
\hline Soil of Farmland & 0.29 & 0.031 & 9.3 & 23.4 \\
Coal Gangue A & 2.63 & 0.092 & 10.6 & 37.8 \\
Coal Gangue B & 2.85 & 0.098 & 10.1 & 35.3 \\
\hline
\end{tabular}

According to the data in the tab.1, 2 and 3, we found the results. The content of $\mathrm{Cd}, \mathrm{Hg}, \mathrm{As}$ and $\mathrm{Pb}$ in the soil of the farmland is less than the content of $\mathrm{Cd}, \mathrm{Hg}$, $\mathrm{As}$ and $\mathrm{Pb}$ in the coal gangue. The heavy metal content of different time in groundwater of reclamation area is more than the heavy metal content in control groundwater of individual well. Contrast with the quality standard values of soil environment, we could find: the heavy metal content in the soil nearby individual well belongs to the primary standard; the content of $\mathrm{Hg}$ and $\mathrm{As}$ in the coal gangue of $\mathrm{A}$ and $\mathrm{B}$ belong to the primary standard; while, the content of $\mathrm{Cd}$ and $\mathrm{Pb}$ belongs to the secondary standard; the $\mathrm{Cd}$ content of the coal gangue is much more than the $\mathrm{Cd}$ content in the secondary standard of the soil. Thus, it could have the potential risks of pollution on the surrounding ecological environment.

\section{B. The Change Characteristics of the Heavy Metal Content and the Correlation with the Reclamation Time}

(1) The change characteristics of the heavy metal $\mathrm{Cd}$ content of the groundwater and the correlation with the reclamation in the reclamation area.

Figure 1 is the change trend of the $\mathrm{Cd}$ content in groundwater of the monitoring wells of $\mathrm{A}$ and $\mathrm{B}$. According to the table 1 and figure 1, we found: the $\mathrm{Cd}$ content in groundwater is in the process of rising in the reclamation of 2.5 years. The $\mathrm{Cd}$ content of the monitoring well $\mathrm{A}$ is more than the $\mathrm{Cd}$ content of the monitoring well 8 B. The Cd content in the groundwater of the reclamation area is obviously higher than the heavy metal content in 1 control groundwater of individual well. The $\mathrm{Cd}$ content of the coal gangue which is filling material is higher than the Cd content of the content of control soil. The Cd content 9.2 in groundwater is in the process of rising in the reclamation of 2.5 years, while the water could be used for various purposes in accordance with the national 9.2 groundwater quality standard. The water doesn't have the potential risks.

Through the reclamation time and $\mathrm{Cd}$ content in groundwater by regression analysis, we could find that the reclamation time associated with the $\mathrm{Cd}$ content of groundwater in linear time, the content of $\mathrm{Cd}$ increases with the increase of reclamation time. The correlation between the $\mathrm{Cd}$ content of monitoring well $\mathrm{B}$ and the reclamation time is smaller than the $\mathrm{Cd}$ content of monitoring well $\mathrm{A}$ and the reclamation time. The $\mathrm{Cd}$ content of the groundwater in monitoring wells A and B have the basically same change trend.

Fig.1 Changes of Cd Content in Different Monitoring Wells and the Correlation with the Reclamation Time

(2) The change characteristics of the heavy metal $\mathrm{Hg}$ content of the groundwater and the correlation with the reclamation in the reclamation area 


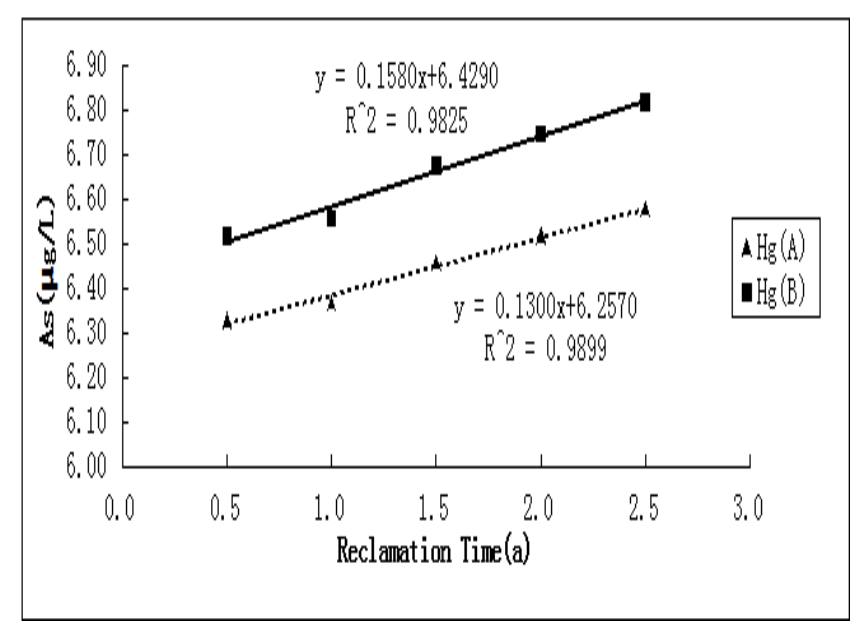

Figure 2 is the change trend of the $\mathrm{Hg}$ content in groundwater of the monitoring wells of $\mathrm{A}$ and $\mathrm{B}$. According to Table 1 and Figure 2, we found: the $\mathrm{Hg}$ content in groundwater is in the process of rising in the reclamation of 2.5 years. The $\mathrm{Hg}$ content of the monitoring well $\mathrm{B}$ is more than the $\mathrm{Hg}$ content of the monitoring well $\mathrm{A}$. The $\mathrm{Hg}$ content in the groundwater of the reclamation area is obviously higher than the heavy metal content in control groundwater of individual well. Therefore, the coal gangue $\mathrm{Hg}$ content has no effect on the improvement of the $\mathrm{Hg}$ content in groundwater. $\mathrm{The} \mathrm{Hg}$ content of the coal gangue is higher than that in the control soil .It may be one of the influence factors which increase the $\mathrm{Hg}$ content of the groundwater. The $\mathrm{Hg}$ content in groundwater is in the process of rising in the reclamation of 2.5 years, while the water could be used for various purposes in accordance with the national groundwater quality standard. The water doesn't have the potential risks.

Through the reclamation time and $\mathrm{Hg}$ content in groundwater by regression analysis, we could find that the reclamation time associated with the $\mathrm{Hg}$ content of groundwater in linear time, the content of $\mathrm{Hg}$ increases with the increase of reclamation time. The correlation between the $\mathrm{Hg}$ content of monitoring well $\mathrm{A}$ and the reclamation time is smaller than that between the $\mathrm{Hg}$ content of monitoring well $\mathrm{B}$ and the reclamation time. The $\mathrm{Hg}$ content of monitoring well $\mathrm{B}$ and the reclamation time has the significant correlation. The $\mathrm{Hg}$ content of the groundwater in monitoring wells $\mathrm{A}$ and $\mathrm{B}$ have the basically same change trend.

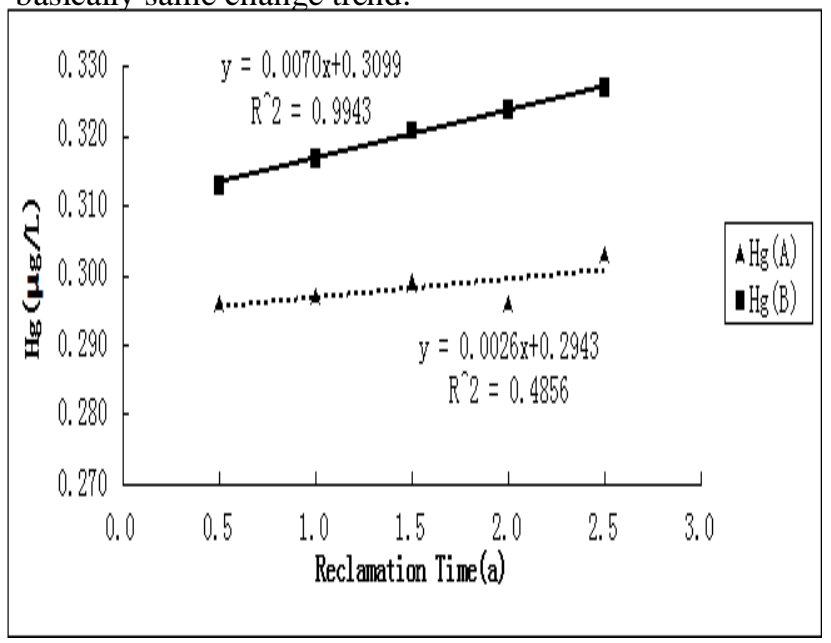

Fig.2 Changes of $\mathrm{Hg}$ Content in Different Monitoring Wells and the Correlation with the Reclamation Time

(3) The change characteristics of the heavy metal As content of the groundwater and the correlation with the reclamation in the reclamation area

Figure 3 is the change trend of the As content in groundwater of the monitoring wells of $\mathrm{A}$ and $\mathrm{B}$. According to the table 1 and figure 3, we found: the As content in groundwater is in the process of rising in the reclamation of 2.5 years. The As content of the monitoring well $\mathrm{B}$ is more than the As content of the monitoring well A. The As content in the groundwater of the reclamation area is obviously less than the heavy metal content in control groundwater of individual well. Therefore, the coal gangue As content has an effect on the improvement of the As content in groundwater. The As content of the coal gangue is higher than that in the control soil .It may be one of the influence factors which increase the As content of the groundwater. The As content in groundwater is in the process of rising in the reclamation of 2.5 years, while the water could be used for various purposes in accordance with the national groundwater quality standard. The water don't have the potential risks.

Through the reclamation time and As content in groundwater by regression analysis, we could find that the reclamation time associated with the As content of groundwater in linear time, the content of As increases with the increase of reclamation time. The As content of monitoring wells $\mathrm{A}$ and $\mathrm{B}$ and the reclamation time have the significant correlation. The As content of the groundwater in monitoring wells $\mathrm{A}$ and $\mathrm{B}$ have the basically same change trend.

Fig.3 Changes of As Content in Different Monitoring Wells and the Correlation with the Reclamation Time

(4) The change characteristics of the heavy metal Pb content of the groundwater and the correlation with the reclamation in the reclamation area

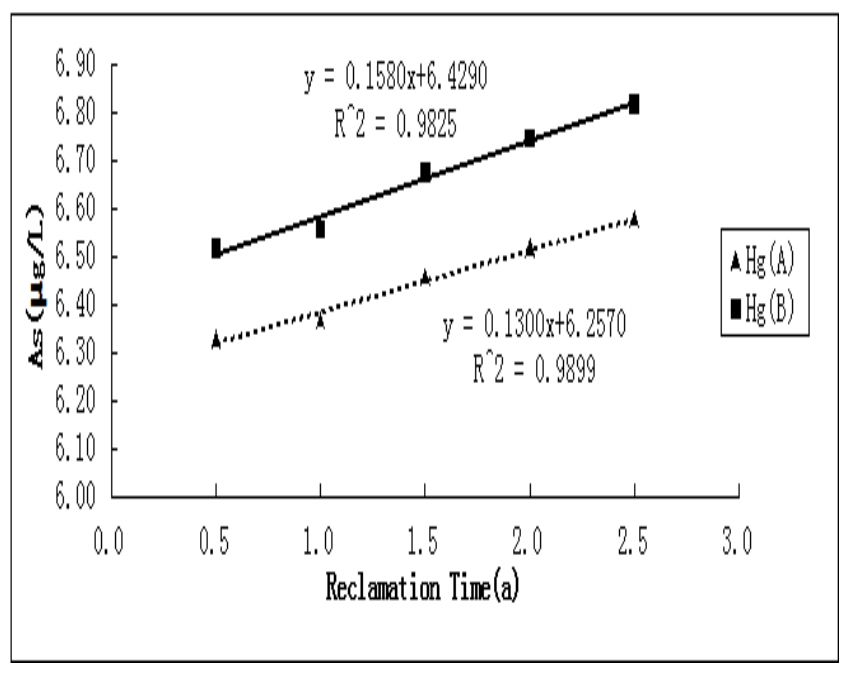

Figure 4 is the change trend of the $\mathrm{Pb}$ content in groundwater of the monitoring wells of $\mathrm{A}$ and $\mathrm{B}$. According to Table 1 and Figure 4, we found: the $\mathrm{Pb}$ content in groundwater is in the process of rising in the reclamation of 2.5 years. The $\mathrm{Pb}$ content of the monitoring well $\mathrm{B}$ is less than the $\mathrm{Pb}$ content of the monitoring well $\mathrm{A}$. 
The $\mathrm{Pb}$ content in the groundwater of the reclamation area is obviously higher than the heavy metal content in control groundwater of individual well. Therefore, the $\mathrm{Pb}$ content of the coal gangue has an effect on the improvement of the $\mathrm{Pb}$ content in groundwater. The $\mathrm{Pb}$ content of the coal gangue is higher than that in the control soil .It may be one of the influence factors which increase the $\mathrm{Pb}$ content of the groundwater. The $\mathrm{Pb}$ content in groundwater is in the process of rising in the reclamation of 2.5 years, while the water could be used for various purposes in accordance with the national groundwater quality standard. The water doesn't have the potential risks.

Through the reclamation time and $\mathrm{Pb}$ content in groundwater by regression analysis, we could find that the reclamation time associated with the $\mathrm{Pb}$ content of groundwater in linear time, the content of $\mathrm{Pb}$ increases with the increase of reclamation time. The $\mathrm{Pb}$ content of monitoring wells $\mathrm{A}$ and $\mathrm{B}$ and the reclamation time have the significant correlation. The $\mathrm{Pb}$ content of the groundwater in monitoring wells $\mathrm{A}$ and $\mathrm{B}$ have the basically same change trend.

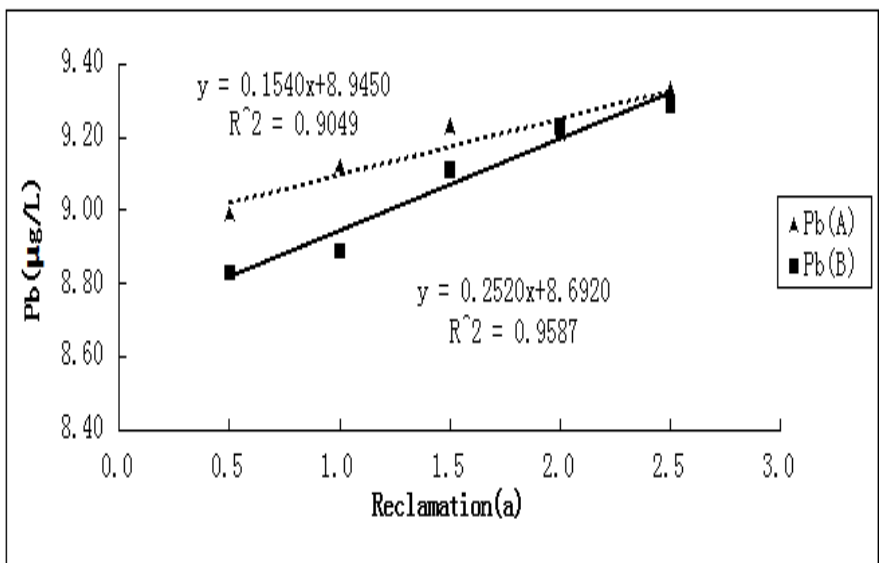

Fig.4 Changes of $\mathrm{Pb}$ Content in Different Monitoring Wells and the Correlation with the Reclamation Time

Conclusions

(1)The heavy metal content of the $\mathrm{Cd}, \mathrm{Hg}$, As and $\mathrm{Pb}$ increased with the increase of reclamation time, and they are all higher than the heavy metal content in control groundwater of individual well. The heavy metal content in the soil nearby individual well is less than that in the coal gangue of reclamation land.

(2)The heavy metal content of groundwater associated with the reclamation time in linear time. The correlation between the $\mathrm{Cd}$ content in groundwater and the reclamation time is not significant. The correlation between the $\mathrm{Hg}$ content in groundwater and the reclamation time was not significant in the monitoring well $\mathrm{A}$, but that in the monitoring well $\mathrm{B}$ is significant.
The correlation between the As content in groundwater and the reclamation time is very significant. The correlation between the $\mathrm{Pb}$ content in groundwater and the reclamation time is very significant.

(3) The heavy metal content in groundwater is in the process of rising in the reclamation time, while the water could be used for various purposes in accordance with the national groundwater quality standard. The water doesn't have the potential risks.

\section{REFERENCES}

[1] Xu Liangji, Huang Can, Zhang Ruqin, et al. Physical and chemical properties and distribution characteristics of heavy metals in reclaimed land filled with coal gangue $[\mathrm{J}]$. Transactions of the Chinese Society of Agricultural Engineering (Transactions of the CSAE), 2014, 30(5): 211-219.

[2] MA Jianjun, ZHANG Shuli, YAO Hong, et al. Temporal cumulative effects of heavy metal and metalloid elements in covering soil of opencast coal mine reclamation area[J]Journal of Arid Land Resources and Environment,2012,26(12):69-74.

[3] Xu Liangii, Yan Jiaping, Yang Xiufang. Study on distribution character of physical and chemical properties and heavy metals in reclaimed land filled with fly ash-A case study of reclaimed land of Luohe power plant in Huainan city[J]. Journal of Agro-Environment Science,2012,31(12): 2352-2360.

[4] Liu Huiping, Yan Jiaping, Fan Wen. The evaluation of soil productivity in reclamation district filling by coal gangue with different thickness of covering soil[J]. Energy environmental protection, 2010, 24(1): 52-56.

[5] Li Xinju, Hu Zhenqi, Li Jing, et al. Research progress of reclaimed soil quality in mining subsidence area[J]. Transactions of the Chinese Society of Agricultural Engineering (Transactions of the CSAE), 2007, 23(6): 276-280.

[6] Li Wei. Study on Changes of Soil Fertility Quality and Groundwater Heavy Metals Pollution in Coal Mine Filled Reclamation Area[D]. Beijing: China University of Mining and Technology, 2011.

[7] Bhuiyan MAH, Parvez L,Islam M A, S.B. Dampare, S. Suzuki. Heavy Metal Pollution of Coal Mine-Affected Agricultural Soils in the Northern Part of Bangladesh [J]. J. Hazard. Mater, 2010, 173(13): 384-392.

[8] Dennis Schlomer,Kevin Nix.Wheat Yield, Plant Nutrients and Physical Properties of Soil Deposits on Fly Ash and Coal Gangue Used for Land Reclamation in the Coal Mining Area of Huainan, China[D].Germany: Osnabrueck University of Applied Science, 2011.

[9] Fan Wen. Study on Reclamation Effect Based on Reclaimed Land Filling with Fly Ash[D]. Huainan:Anhui University of Science and Technology,2010. (in Chinese with English abstract)

[10] Evvie Chockalingam, Subramanian S. Studies on removal of meta ions sulphate eduction using ricehusk and Desulfotomaculum nigrificans with reference to remediation of acid mine drainage [J]. Chemosphere, 2006, 62 (2): 699-708.

[11] Bukowski P,Bromek T,Augustyniak. Using the Drastic System to Assess the Vulnerability of Groundwater to Pollution in Mined Areas of the Upper Silesian Coal Basin [J]. Mine Water and the Environment, 2006, 25(1): 15-22. 